\title{
Hyperosmotic stress-induced microtubule disassembly in Chlamydomonas reinhardtii
}

\author{
Lee Mei Ng${ }^{1}$, Shinichiro Komaki ${ }^{1}$, Hideyuki Takahashi ${ }^{1}$, Takashi Yamano ${ }^{2}$, Hideya Fukuzawa ${ }^{2}$ and \\ Takashi Hashimoto ${ }^{1 *}$
}

\begin{abstract}
Background: Land plants respond to drought and salinity by employing multitude of sophisticated mechanisms with physiological and developmental consequences. Abscisic acid-mediated signaling pathways have evolved as land plant ancestors explored their habitats toward terrestrial dry area, and now play major roles in hyperosmotic stress responses in flowering plants. Green algae living in fresh water habitat do not possess abscisic acid signaling pathways but need to cope with increasing salt concentrations or high osmolarity when challenged with adverse aquatic environment. Hyperosmotic stress responses in green algae are largely unexplored.

Results: In this study, we characterized hyperosmotic stress-induced cytoskeletal responses in Chlamydomonas reinhardtii, a fresh water green algae. The Chlamydomonas PROPYZAMIDE-HYPERSENSITEVE 1 (PHS1) tubulin kinase quickly and transiently phosphorylated a large proportion of cellular a-tubulin at Thr349 in G1 phase and during mitosis, which resulted in transient disassembly of microtubules, when challenged with $>0.2 \mathrm{M}$ sorbitol or $>0.1 \mathrm{M} \mathrm{NaCl}$. By using phs 1 loss-of-function algal mutant cells, we demonstrated that transient microtubule destabilization by sorbitol did not affect cell growth in G1 phase but delayed mitotic cell cycle progression. Genome sequence analyses indicate that PHS1 genes evolved in ancestors of the Chlorophyta. Interestingly, PHS1 genes are present in all sequenced genomes of freshwater Chlorophyta green algae (including Chlamydomonas) but are absent in some marine algae of this phylum.
\end{abstract}

Conclusion: PHS1-mediated tubulin phosphorylation was found to be partly responsible for the efficient stressresponsive mitotic delay in Chlamydomonas cells. Ancient hyperosmotic stress-triggered cytoskeletal remodeling responses thus emerged when the PHS1 tubulin kinase gene evolved in freshwater green algae.

\section{Background}

Colonization of terrestrial environment during land plant evolution required innovations to adapt to desiccation, fluctuation temperatures, and high UV irradiation. For example, key genes that increase resistance to desiccation, such as abscisic acid (ABA) receptor genes, were probably gained by horizontal gene transfer from soil bacteria in the earliest-diverging embryophyte ancestors

\footnotetext{
*Correspondence: hasimoto@bs.naist.jp

${ }^{1}$ Graduate School of Science and Technology, Nara Institute of Science

and Technology, Ikoma, Nara 630-0192, Japan

Full list of author information is available at the end of the article
}

[1]. Diverse green algae dwell in terrestrial freshwater environments. Although they do not possess effective stress-response adaptation mechanisms of land plants, freshwater green algae need to respond and adapt to occasional dehydration and salt challenges. Such primitive or ancient stress responsive mechanisms are largely unknown.

Propyzamide hypersensitive 1 (PHS1) was discovered in a flowering plant Arabidopsis thaliana that mediates hyperosmotic stress to remodel the microtubule cytoskeleton [2]. PHS1 consists of an N-terminal tubulin kinase domain and a C-terminal phosphatase domain [3]. Under unstressed growth conditions, the phosphatase 
activity suppresses the tubulin kinase activity, thereby maintaining the kinase in an inactive state. Upon moderate hyperosmotic stress, the tubulin kinase is immediately activated and phosphorylates Thr349 of $\alpha$-tubulin. Since the phosphorylated tubulin does not readily assemble into a microtubule polymer, cellular microtubules containing phosphorylated tubulins become shortly disassembled [3]. In vitro, purified tubulin populations containing the Thr349-phosphorylated forms do not readily polymerize [4]. However, it is not known how such microtubule disassembly affects plant performance under stress, and whether PHS1-mediated stress responses occur in other plants, especially in aquatic non-land plants. In this study, we characterized a PHS1 tubulin kinase in Chlamydomonas reinhardtii, a model freshwater algal species belonging to the Chlorophytes phylum.

\section{Results}

\section{Establishment of synchronized Chlamydomonas cell} cultures

In order to analyze cell growth and cell biological phenotypes separately in G1 phase and mitosis, growth of Chlamydomonas reinhardtii (CC-4533 strain) was synchronized by adjusting an inoculum at the beginning of the culture and by alternating the illumination in a $12 \mathrm{~h}$ light- $12 \mathrm{~h}$ dark cycle. The number, the size and the morphology were analyzed by using a coulter counter and a light microscopy. The cell size showed Gaussian distribution patterns (Fig. S1), and the size distribution peaks increased while maintaining the initial cell number until the 12th $\mathrm{h}$, when the cells increased the cell volume approximately eight-fold (Fig. 1A). After the onset of the dark period at the 12th $h$, the number of free daughter cells began to increase and, by the 16th $\mathrm{h}$, the cell number increase stopped, and all the cells were small as the beginning of the culture. Microscopic images of individual cells at each cell cycle stage supported the coulter counter analyses, and further showed that Chlamydomonas cells formed daughter cell clusters that peaked at the 12th to 13th h (Fig. 1B). Individual daughter cells in a cell cluster were released (i.e., hatched) after the 14th $\mathrm{h}$. The cell number analysis by the coulter counter does not differentiate cell aggregates from free single cells. Expression patterns of two cell-cycle regulated genes were analyzed by reverse transcription qPCR. $C D K B$ and $C Y C B$ are a cyclin-dependent kinase gene and a cyclin gene, respectively, which are specifically up-regulated during the S/M phase of the Chlamydomonas cell cycle $[5,6]$. The expression levels of these two genes were low at the beginning of the synchronized culture, increased sharply at the 10th $\mathrm{h}$ before the start of the dark period, and then started to
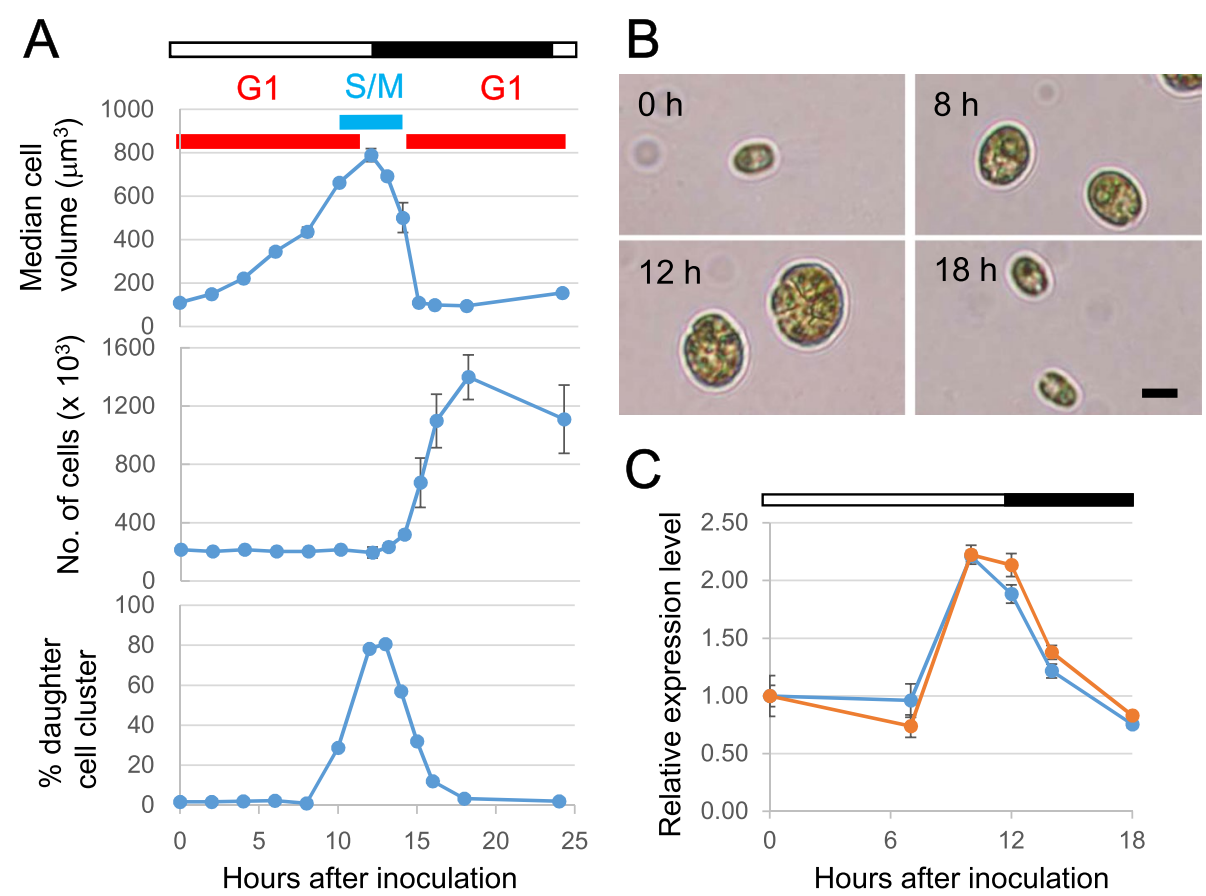

Fig. 1 Synchronized Chlamydomonas cell cultures. (a) Cell growth and formation of daughter cells. Estimated cell cycle phases are indicated. Cells were illuminated (white bar) or grown in the dark (black bar). (b) Cell morphology at the indicated time point after inoculation, analyzed by light microscopy. Bar: $10 \mu \mathrm{m}$. (c) Relative expression levels of CDKB (blue) and CYCB (orange) during culture. White and black bars respective indicate light and dark periods. Error bars indicate standard deviations from three biological replicates 
decrease after 12th h (Fig. 1C). Altogether, these analyses show that a high level of cell cycle synchronization was attained and that under our synchronization conditions the cells are in the G1 phase from the start of the culture to the 10th $\mathrm{h}$, while the mitosis occurs between the 10th and the 13th $\mathrm{h}$.

\section{Tubulin is phosphorylated under salt and osmotic stress in Chlamydomonas}

Commercial artificial seawater was applied to the Chlamydomonas cells in $\mathrm{G} 1$ phase for $10 \mathrm{~min}$ at the concentrations of 10,20, 40 and $60 \%$. Tubulin phosphorylation was analyzed by a specific phosphor-tubulin antibody. This antibody was raised against a phospho-peptide (N-FVDWCPpTGFKCGIN-C) targeting the Thr349 of Arabidopsis $\alpha$-tubulin [4]. This peptide sequence is perfectly conserved in the two $\alpha$-tubulins of $C$. reinhardtii. The immunoblot detected $\alpha$-tubulin phosphorylation at Thr349 at 20 and $40 \%$ of seawater but not at 0,10 and $60 \%$ (Fig. 2A). Phosphorylation of $\alpha$-tubulin at Thr349 was previously detected in the non-targeted phosphorproteome analysis of $C$. reinhardtii proteins [7]. The salt concentration at $40 \%$ seawater corresponds to $\sim 0.17 \mathrm{M}$ $\mathrm{NaCl}$ equivalent. At $60 \%$ seawater, the cells did not grow at all, indicating that the treated cells are physiologically dormant or dying.

Both sorbitol and salt induce hyperosmotic stress to the cells, while the effects of high concentrations of salt also involve cellular ion imbalance [8]. When the effects of sorbitol and $\mathrm{NaCl}$ were compared at the similar osmolarity, comparable levels of the tubulin phosphorylation were observed. When Chlamydomonas cells were treated by $0.3 \mathrm{M}$ sorbitol or $0.15 \mathrm{M} \mathrm{NaCl}$, tubulins were phosphorylation at similar levels after $10 \mathrm{~min}$ (Fig. 2B). These concentrations of sorbitol and $\mathrm{NaCl}$, however, affected the cell growth differently; $\mathrm{NaCl}$ at $0.15 \mathrm{M}$ inhibited the cell volume increase much more severely than sorbitol at $0.3 \mathrm{M}$ (Fig. S2). These results suggest that the tubulin phosphorylation is mainly caused by hyperosmotic stress and that the inhibition of cell growth by salt involves effects other than the osmotic stress.

Since the CC-4533 strain possesses a $c w 15$ wall-deficient mutation [9], other laboratory strains of C. reinhardtii were also examined. The $\mathrm{C} 9$ and $\mathrm{CC}-125$ strains possess normal cell wall, whereas the CC-5155, CC-5325 and CC-4533 strains also are defective in cell wall components (Chlamydomonas Resource Center; https://www. chlamycollection.org/). These strains were treated either with $\mathrm{NaCl}$ or sorbitol for $20 \mathrm{~min}$, and then analyzed for tubulin phosphorylation. The immunoblot results in Fig. S3 showed that all strains, regardless of intact or defective cell walls, phosphorylated $\alpha$-tubulin upon treatment with $0.1-0.2 \mathrm{M} \mathrm{NaCl}$ and with $0.2 \mathrm{M}$ sorbitol. Thus, the stress-induced tubulin phosphorylation does not depend on the cell wall status.

\section{PHS1 mediates stress-induced tubulin phosphorylation}

The single-copy PHS1 gene (Cre08.g375000) is located at chromosome 8 of $C$. reinhardtii, consists of 17 exons and 16 introns, and potentially encodes a polypeptide

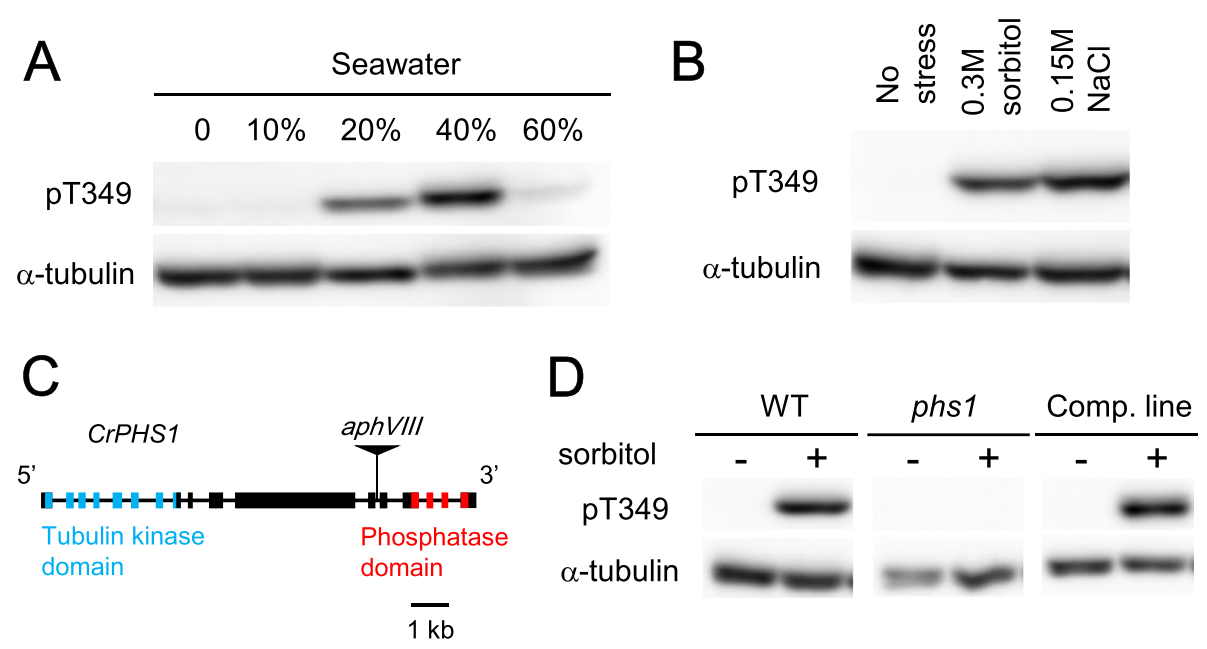

Fig. 2 PHS1 phosphorylates a-tubulin in response to hyperosmotic stress. Immunoblots using an antibody specifically recognizing a-tubulin phosphorylated at Thr349 (pT349) or a general antibody for a-tubulin. Experiments were repeated at least once with similar results. (a) Cells were treated with sea water at the indicated levels for $10 \mathrm{~min}$. (b) Cells were treated with $0.3 \mathrm{M}$ sorbitol or $0.15 \mathrm{M} \mathrm{NaCl}$ for $10 \mathrm{~min}$. (c) Gene structure of C. reinhardtii, PHS1. The boxes and connecting lines indicate exons and introns, respectively. Insertion site of the aphVIII gene is shown. The tubulin kinase and phosphatase domains are shown in blue and red boxes, respectively. (d) Sorbitol treatment at $0.2 \mathrm{M}$ for $10 \mathrm{~min}$ triggered tubulin phosphorylation in wild-type and complemented cells, but not in phs 1 mutant cells 
of 1905 amino acid residues. The positions of introns were supported by an RNAseq analysis (H. Fukuzawa, personal communication). To examine whether Chlamydomonas PHS1 is responsible for the observed tubulin phosphorylation, as shown in Arabidopsis [3], a PHS1 insertion mutant, in which paromomycin resistance aphVIII gene was inserted in the PHS1 locus, was obtained (Fig. 2C). A PHS1 genomic fragment was transformed to this phs1-1 allele, hereafter simply described as phs1. Genomic PCR analyses confirmed that PHS1 was disrupted by aphVIII gene in phs1 and its complementation line, whereas an intact PHS1 region of $1.2 \mathrm{~kb}$ was present in the genomes of both wild type and the complementation line (Fig. S4). Treatment of $0.2 \mathrm{M}$ sorbitol for $10 \mathrm{~min}$ induced tubulin phosphorylation in wild type and the complementation line, but not in phs1, indicating recovery of a tubulin kinase activity by the introduction of the wild-type PHS1 copy in the PHS1 null mutant (Fig. 2D). Thus, PHS1 is solely responsible for the hyperosmotic stressinduced $\alpha$-tubulin phosphorylation at Thr349 in Chlamydomonas cells.

\section{Sorbitol-triggered tubulin phosphorylation is rapid and transient, and occurs in $\mathrm{G} 1$ phase and mitosis}

Effects of sorbitol were studied in G1 phase (at the 6th $\mathrm{h}$ after inoculation) and mitosis (at the 11th h; Fig. 3A). In the $\mathrm{G} 1$ phase cells, sorbitol at $0.2 \mathrm{M}$ and $0.3 \mathrm{M}$ induced high tubulin phosphorylation after $10 \mathrm{~min}$ of stress treatment; thereafter, tubulins were swiftly dephosphorylated within $1 \mathrm{~h}$. In the mitotic cells, similar patterns of tubulin phosphorylation and dephosphorylation were observed, but there were low levels of phosphorylated tubulins often detected even in the absence of the stress, and tubulin dephosphorylation took somewhat longer time to complete.

To determine how much tubulins are phosphorylated, we used a phosphor-protein-interacting chemical, the phos-tag [10], to separate phosphorylated and non-phosphorylated proteins in the phos-tag-containing SDS PAGE gels (Fig. 3B, C). The peaks of tubulin phosphorylation occurred after $10 \mathrm{~min}$ (G1 phase) and $30 \mathrm{~min}$ (mitosis) of $0.3 \mathrm{M}$ sorbitol treatment, and more than $60 \%$ of cellular tubulins were phosphorylated at the peaks. Lower levels of tubulin phosphorylation in the G1 phase cells may reflect that the flagellar microtubules are highly stable and only exchange with cellular tubulins at the flagellar tips $[11,12]$.

These results demonstrate that hyperosmotic stress induces rapid, massive, and transient tubulin phosphorylation in both G1 phase and mitotic cells of $C$. reinhardtii.

\section{Microtubules are transiently disassembled by PHS1 in sorbitol-treated cells}

To examine the consequences of stress-induced transient tubulin phosphorylation on microtubule organization, cytoplasmic microtubules were labeled by both anti- $\alpha$-tubulin antibody and anti-acetylated- $\alpha$-tubulin antibody. Acetylated tubulins are preferentially present in stable and long-lived microtubules and protect microtubules from mechanical breakage [13]. In G1 phase cells, four microtubule bundles, called "rootlets" extend from the basal body toward the other end of the cell body along the cell periphery, and are known to contain acetylated tubulins, indicating their partial stability [14].

In the non-stressed control cells, a few thick microtubule bundles that often contain some acetylated tubulins were discernible and most likely represent microtubule rootlets (Fig. 4A). Flagellar microtubules are heavily acetylated [15], and were also strongly stained in this study. Microtubule organizations were indistinguishable among wild type, phs1, and its complementation line. Upon sorbitol treatment for $10 \mathrm{~min}$, microtubules in wild type and the complementation line were considerably depolymerized, whereas such rapid microtubule disassembly did not occur in phs1. After $1 \mathrm{~h}$ of the stress treatment, microtubule organization in wild type and the complementation line recovered to the initial non-stress levels. These results indicate that the PHS1-mediated tubulin phosphorylation leads to transient microtubule instability in G1 phase cells. Such stress-trigged microtubule reorganization is effective only for a short time window of less than $1 \mathrm{~h}$. Microtubule density in each cells was calculated as "microtubule occupancy", which was derived by dividing the microtubule area by whole cell area, after conversion of original $\alpha$-tubulin immuno-stained images to binary images by Image J (Fig. S5). Quantification and statistical analysis of the microtubule polymer density in cells confirmed these results (Fig. 4B).

\section{Cell division, but not cell growth, is affected by PHS1-mediated microtubule destabilization}

Since the above results show that hyperosmotic stress depolymerizes cytoplasmic microtubules for a short period (less than $1 \mathrm{~h}$ ), we first examined whether such a transient microtubule destabilization affects cell growth during G1 phase. In Chlamydomonas cells in which cell growth and cell division are partially uncoupled, how fast cells grow during a prolonged $\mathrm{G} 1$ phase determines how many fission cycles occur after the light period [16]. Hyperosmotic stress was applied at the onset of synchronization culture by inoculating Chlamydomonas cells into culture media containing $0.2 \mathrm{M}$ or $0.3 \mathrm{M}$ sorbitol. 


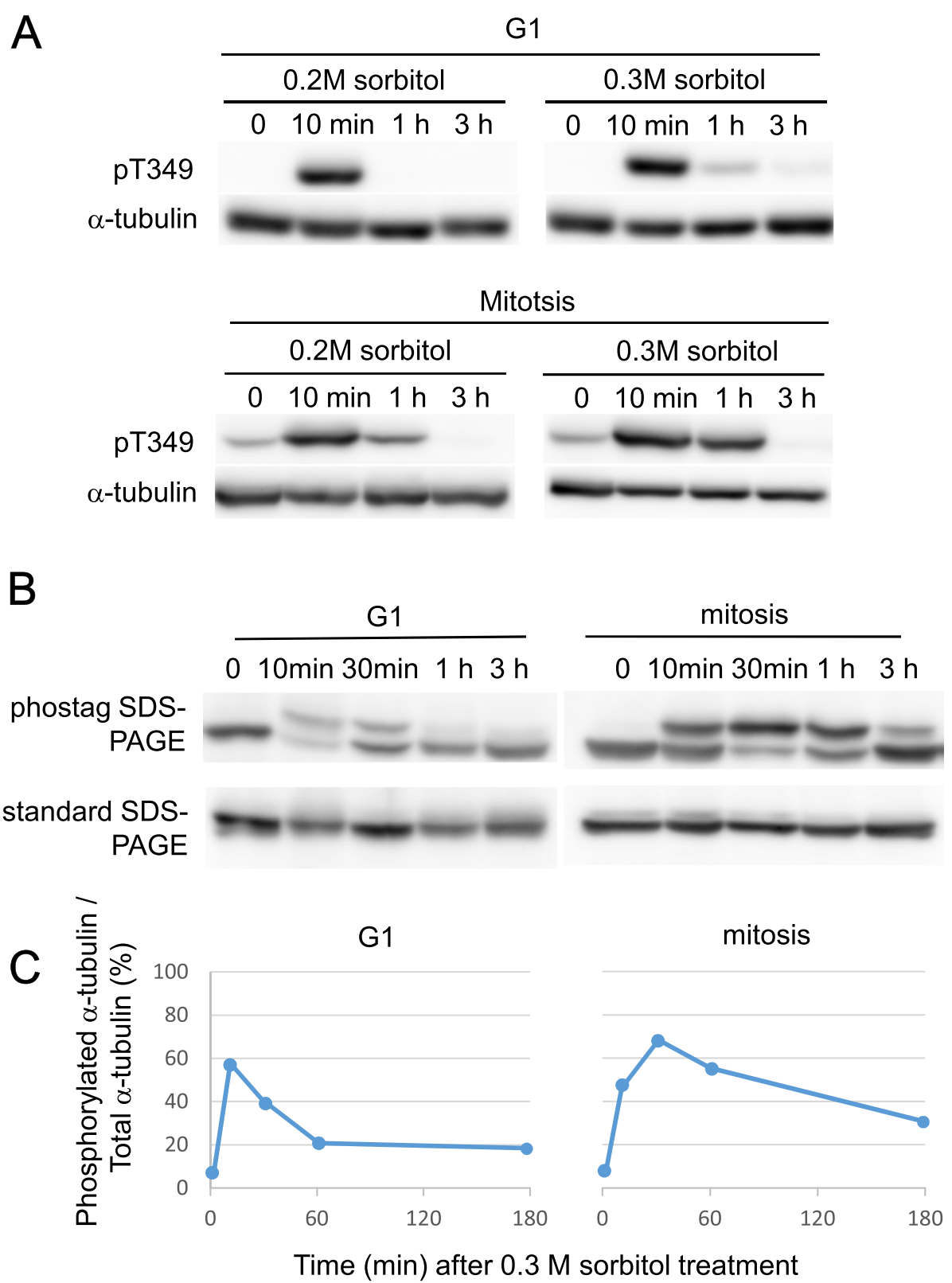

Fig. 3 Time courses of stress-induced tubulin phosphorylation. Experiments were repeated at least once with similar results. (a) Cells were treated by $0.2 \mathrm{M}$ or $0.3 \mathrm{M}$ sorbitol at $\mathrm{G} 1$ or mitosis. Immunoblots used antibodies indicated in the legend of Fig. 2. (b) Phos-tag SDS-PAGE blots show that phosphorylated tubulins (upper bands) constituted large tubulin fractions after the $0.3 \mathrm{M}$ sorbitol stress. Standard SDS-PAGE blots, which did not distinguish tubulin modifications, are also shown for comparison. General anti-a-tubulin antibody was used for analyses. (c) Percentages of phosphorylated tubulins in total tubulins were quantified by image analyses of (b)

During the G1 phase duration up to $9 \mathrm{~h}$, no increase in the cell number in culture was observed while the individual cell size kept increasing, as monitored by the coulter counter. Growth rates (i.e. increase in cell volume) were calculated for the initial lag phase (up to $3 \mathrm{~h}$ after inoculation) and for the later accelerated growth phase (from 6 to $9 \mathrm{~h}$ ). Increasing concentrations of sorbitol inhibited cell growth more strongly during the accelerated growth phase, but the growth rates for both phases were indistinguishable among wild type, phs1, and the complementation line (Fig. 5). These results show that PHS1 does not play any obvious roles in cell growth during G1 phase of sorbitol-stressed cells. 


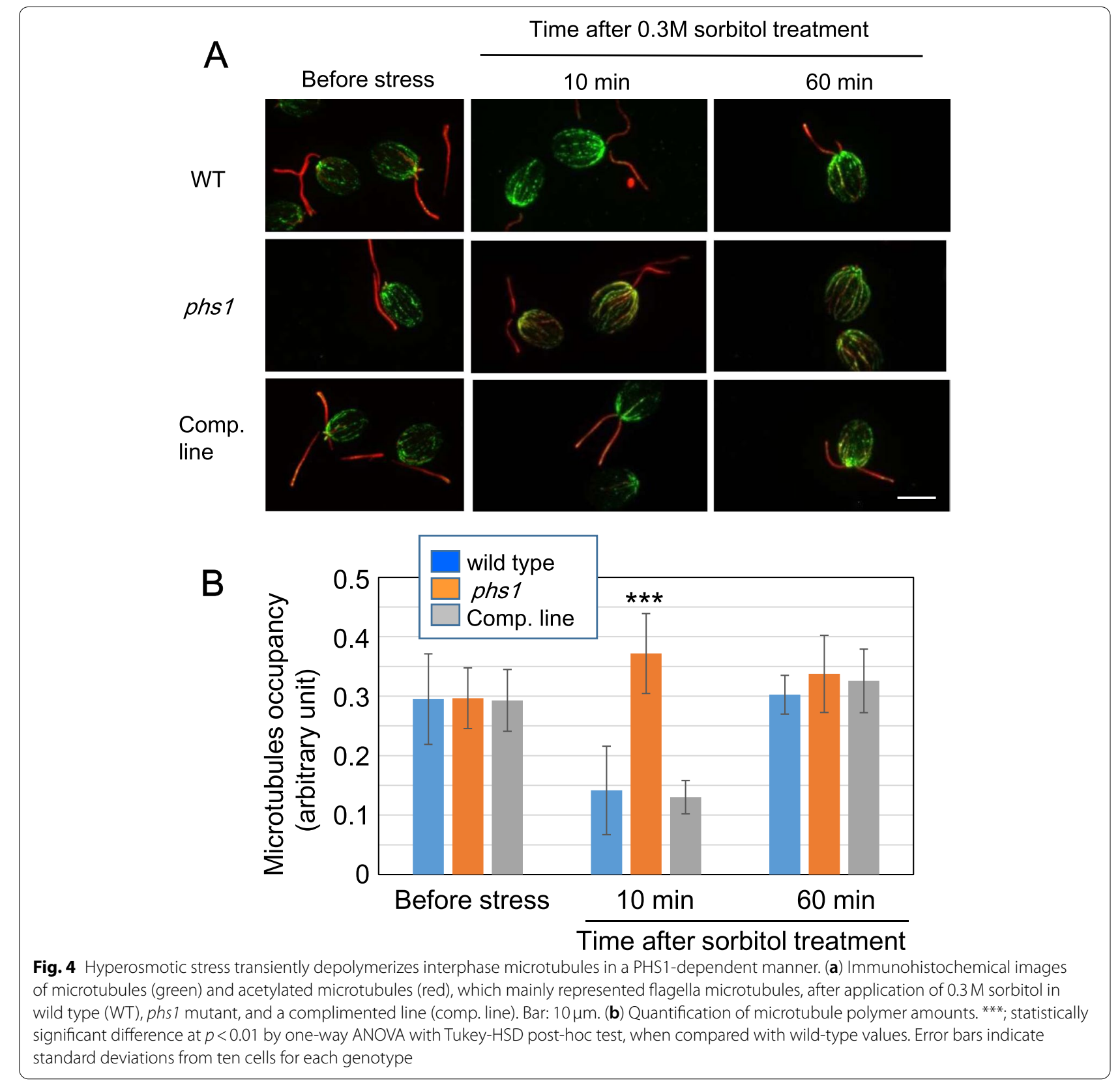

\section{Time after $0.3 \mathrm{M}$ sorbitol treatment}

Next, dividing cells were targeted for osmotic stress, by applying $0.3 \mathrm{M}$ sorbitol at the 9 th $\mathrm{h}$, just before the onset of mitosis. Under non-stressed conditions, Chlamydomonas cells transiently formed cell clusters containing four or eight daughter cells encapsulated within the mother cell wall, from which free daughter cells hatched within a few hours (see Fig. 1a). Bright field microscopic images showed that sorbitol stress treatment strongly inhibited hatching in three genotypes, so that newly divided daughter cells remained associated for several hours (Fig. 6A). In the time frame of our experiments (up to $12 \mathrm{~h}$ in the stressed conditions), no free daughter cells were released, as indicated by no net increase in the combined number of single cells and cell aggregates after the stress (Fig. 6B). Formation of daughter cell clusters were delayed, but not strongly inhibited, by the stress in three genotypes, indicating that mild hyperosmotic stress delayed progression of mitosis. However, we found that mitotic progression was less affected in the phs1 cells, compared to wild-type cells and the complemented cells. Formation of daughter cells were already observed after $3 \mathrm{~h}$ of stress application (the 12th $\mathrm{h}$ after the onset of 


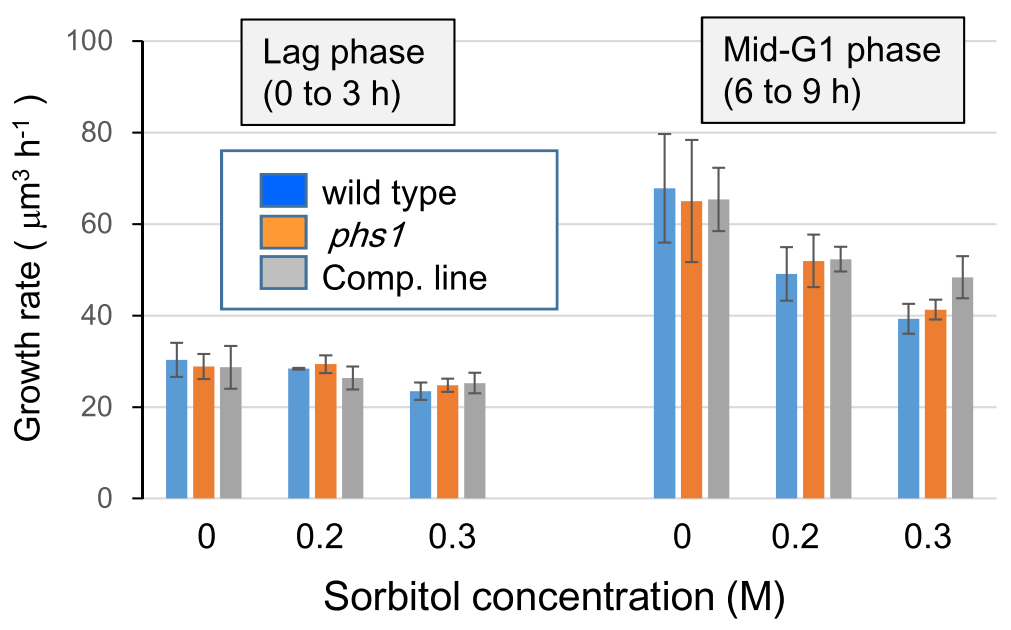

Fig. 5 Sorbitol stress does not inhibit cell growth during G1. Growth rates in terms of increase in cell volume were monitored during a lag phase and a mid-G1 phase when cells of three genotypes (wild type, phs 1 mutant, a complementation line) were cultured in the presence of $0 \mathrm{M}, 0.2 \mathrm{M}$, or $0.3 \mathrm{M}$ sorbitol. Error bars indicate standard deviations from three biological replicates
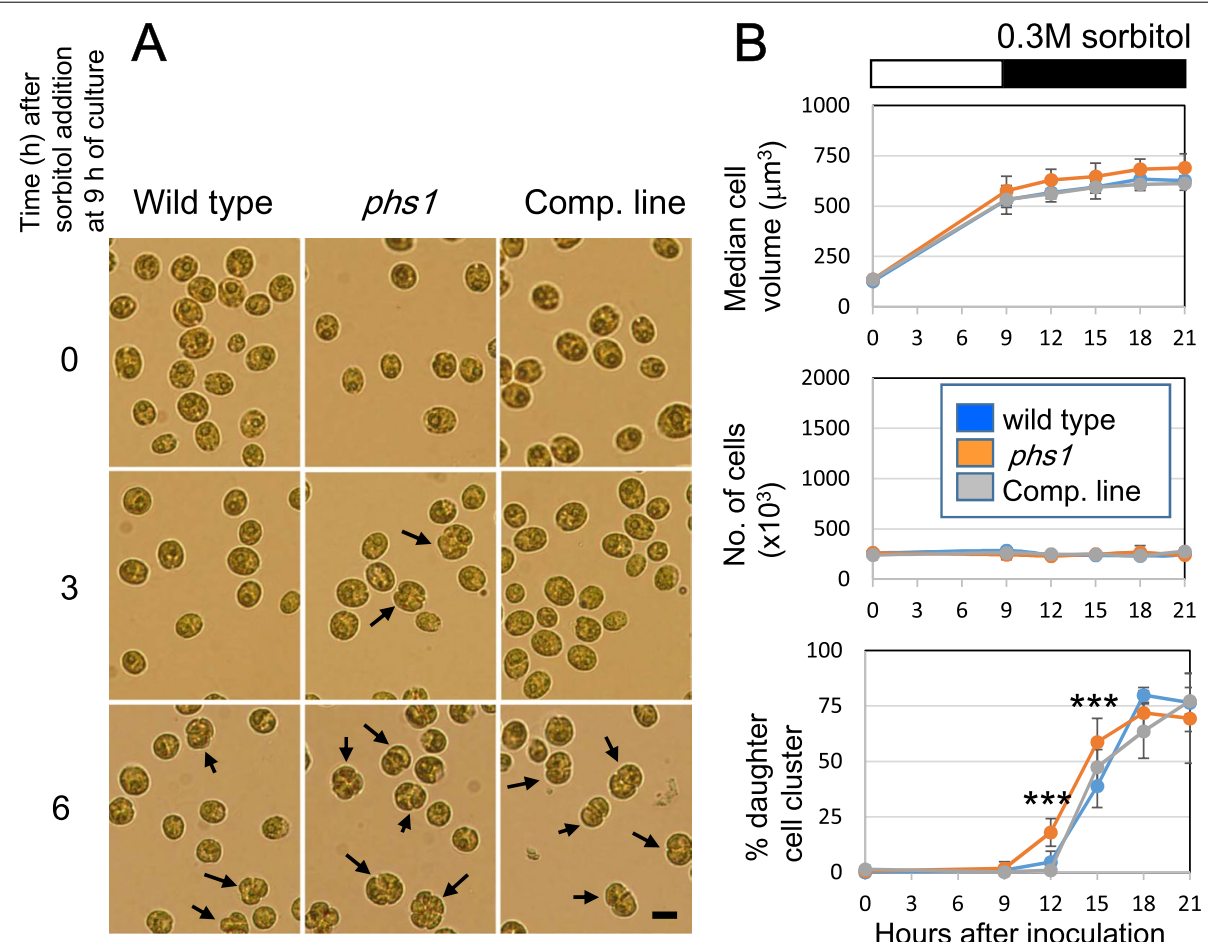

Fig. 6 Hyperosmotic stress-triggered delay in mitotic progression is partly mediated by PHS1. (a) Microscopic cell images of three genotypes (wild type, phs 1 mutant, a complementation line) after $0.3 \mathrm{M}$ sorbitol treatment at $9 \mathrm{~h}$ of culture. Arrows indicate clusters of newly divided daughter cells. (b) Cell growth and formation of daughter cell clusters. Sorbitol at $0.3 \mathrm{M}$ was applied at $9 \mathrm{~h}$ after the start of culture (during the period indicated by a black bar). ${ }^{* *}$; statistically significant difference at $p<0.01$ by one-way ANOVA with Tukey-HSD post-hoc test, when compared with wild-type values. Error bars indicate standard deviations from five biological replicates

culture) in the phs1 cells, but not in wild-type cells and the complimented cells (Fig. 6A, B). These results indicate that the delayed cell cycle progression after the stress was partly caused by the PHS1 functions.

\section{PHS1 genes in algae}

Presence of a functional PHS1 gene in C. reinhardtii prompted us to search possible presence of algal PHS1 genes in the sequenced genomes. Since the tubulin 
kinase domain possessing an atypical kinase domain with high homology to the unique actin-fragmin kinase domain [17] is a hallmark of the evolution of PHS1, we first searched the presence of the tubulin kinase-like sequences. Kinase domains with high sequence similarity to the tubulin kinase domain were not found in the genomes of red algae. However, tubulin kinase domains were identified in many (but not all) genomes of green algae (Table 1). Every algae protein possessing a putative tubulin kinase had a Mitogen-activated Protein Kinase (MPK) phosphatase-like domain in its C-terminus. Therefore, these proteins share the overall domain architecture of PHS1.

In Chlorophyta, PHS1 genes are present in nine Chlorophyceae species (Chlamydomonas reinhardtii, Chlamydomonas eustigma, Chlamydomonas incerta, Chlamydomonas schloesseri, Chromochloris zofingiensis, Edaphochlamys debaryana, Gonium pectoral,
Monoraphidium neglectum, and Scenedesmus sp. NREL 46B-D3), five Trebouxiophyceae species (Picochlorum soloecismus, Auxenochlorella protothecoides, Chlorella variabilis, Coccomyxa subellipsoidea, and Micractinium conductrix), and one Maiellophyceae species (Micromonas pusilla). These green algae live in freshwater except for P. soloecismus (brackish water), Scenedesmus sp. (brackish water), and M. pusilla (marine). The tubulin kinase domains in the predicted PHS1 proteins in the S. sp. and M. pusilla contain insertions (105 amino acid residues in Scenedesmus sp., and 17 and 41 amino acid residues in M. pusilla) that are not found in other algal PHS1 sequences (Fig. S6). It is noteworthy that two marine green algae, Bathycoccus prasinos (Maiellophyceae) and Dunaliella salina (Chlorophyceae), do not possess any PHS1-like genes in their genomes. Possible correlation between the presence of PHS1 and the non-saline habitat is discussed below.

Table 1 PHS1 homologues in the Chlorophyta green algae

\begin{tabular}{|c|c|c|c|c|c|}
\hline \multirow{3}{*}{ Organism } & \multirow{3}{*}{ Class } & \multicolumn{3}{|c|}{ Presence in the genome } & \multirow{3}{*}{ Habitat } \\
\hline & & \multicolumn{2}{|c|}{ Tubulin kinase } & \multirow{2}{*}{$\begin{array}{l}\text { Juxtaposed } \\
\text { phosphatase }\end{array}$} & \\
\hline & & homology & insertion & & \\
\hline Bathycoccus prasinos & Mamiellophyceae & No & --- & --- & Marine \\
\hline Micromonas pusilla & Mamiellophyceae & $38 \%$ & 2 & Yes & Marine \\
\hline Auxenochlorella protothecoides & Trebouxiophyceae & $45 \%$ & 0 & Yes & Freshwater \\
\hline Chlorella variabilis & Trebouxiophyceae & $52 \%$ & 0 & Yes & Freshwater \\
\hline Coccomyxa subellipsoidea & Trebouxiophyceae & $47 \%$ & 0 & Yes & Freshwater \\
\hline Micractinium conductrix & Trebouxiophyceae & $53 \%$ & 0 & Yes & Freshwater \\
\hline Picochlorum soloecismus & Trebouxiophyceae & $49 \%$ & 0 & Yes & Brackish water \\
\hline Chlamydomonas eustigma & Chlorophyceae & $48 \%$ & 0 & Yes & Acidic water \\
\hline Chlamydomonas incerta & Chlorophyceae & $48 \%$ & 0 & Yes & Freshwater \\
\hline Chlamydomonas reinhardtii & Chlorophyceae & $50 \%$ & 0 & Yes & Freshwater \\
\hline Chlamydomonas schloesseri & Chlorophyceae & $48 \%$ & 0 & Yes & Freshwater \\
\hline Chromochloris zofingiensis & Chlorophyceae & $50 \%$ & 0 & Yes & Freshwater \\
\hline Dunaliella salina & Chlorophyceae & No & --- & --- & Marine \\
\hline Edaphochlamys debaryana & Chlorophyceae & $48 \%$ & 0 & Yes & Freshwater \\
\hline Gonium pectoral & Chlorophyceae & $46 \%$ & 0 & Yes & Freshwater \\
\hline Monoraphidium neglectum & Chlorophyceae & $43 \%$ & 0 & Yes & Freshwater \\
\hline Scenedesmus sp. NREL 46B-D3 & Chlorophyceae & $52 \%$ & 1 & Yes & Brackish water \\
\hline
\end{tabular}




\section{Discussion}

\section{PHS1 genes in the plant lineage}

A characteristic feature of the PHS1 structure is the presence of both a unique tubulin kinase domain and a MPK phosphatase-like domain in a single protein sequence. The tubulin kinase domain has a high sequence homology to the atypical kinase domain of the actin-fragmin kinases (which phosphorylate actin) found in slime molds, ciliates, and non-animal holozoans [17-19]. In PHS1, the tubulin kinase domain is situated between the $\mathrm{N}$-terminal kinase interaction motif and the $\mathrm{C}$-terminal phosphatase catalytic domain of a MPK phosphatase-like phosphatase. Since MPK phosphatases are ancient and are present all the eukaryotic organisms [20], insertion of the atypical kinase domain into a MPK phosphatase of an ancient early plants, probably by the horizontal gene transfer from an ancient lower single-celled animal, likely represents a hallmark of the evolution of the plant-specific PHS1 tubulin kinase.

All the sequenced genomes of Rhodophyta (red algae) lack PHS1, whereas many (but not all) green algae (the Chlorophyta division) and all the subsequently evolved plants possess genes encoding PHS1 homologues, indicating that PHS1 evolved in Chlorophyta. The Chlorophyta green algae live in diverse environments, including marine, brackish water, and freshwater. Notably, all the freshwater green algae for which genomes are sequenced (including the Chlorophyceae class) possess apparently intact PHS1 genes, while the two marine green algae, Bathycoccus prasinos (the Mamiellophyceae class) and Dunaliella salina (the Chlorophyceae class), do not show evidence of PHS1 in their genomes. Since PHS1 is activated under the moderate salinity (such as $10 \%$ of sea water), marine habitat with constantly high salinity and high osmotic pressure may be detrimental to organisms possessing PHS1. We speculate that PHS1 genes may have been lost in the marine-living organisms. A possible exception is the marine green algae Micromonas pusilla (the Mamiellophyceae class), in which a full length PHS1 is apparently encoded in its genome. We noted that two insertions disrupt the Micromonas kinase domain, raising a possibility that the tubulin kinase activity is affected by these insertions. A long insertion likewise disrupt the kinase domain of brackish water-living Scenedesmus sp. Tubulin phosphorylation activities of recombinant PHS1 kinase domains from Micromonas and the green algae of the brackish water habitat ( $P$. soloecismus and Scenedesmus sp.) need to be examined to show whether these green algae PHS1 proteins possess functional tubulin kinase activities or not. As more genome sequences of green algae become available, possible association of PHS1 with freshwater habit will be more adequately addressed.

\section{Activation of PHS1 tubulin kinase}

Thr349 of $\alpha$-tubulin is specifically phosphorylated by Arabidopsis PHS1 in planta [3]. Phosphoproteomics in Arabidopsis seedlings revealed that this PHS1-target site is not or barely phosphorylated under unstressed conditions, but becomes increasingly phosphorylated after seedlings are dehydrated for up to $90 \mathrm{~min}$ [21] or are treated $5 \mathrm{~min}$ by $0.3 \mathrm{M}$ mannitol or $0.15 \mathrm{M} \mathrm{NaCl}$ [22]. Phosphorylation of rice $\alpha$-tubulins also becomes apparent after $5 \mathrm{~min}$ of $0.4 \mathrm{M} \mathrm{NaCl}$ or $0.8 \mathrm{M}$ sorbitol treatment of rice seedling roots [23]. Immunohistochemical analysis of Arabidopsis leaf epidermal cells showed that interphase cortical microtubules become more disassembled after $10 \mathrm{~min}$ of $0.8 \mathrm{M}$ sorbitol treatment, concomitant with increase of tubulin phosphorylation [3]. These results demonstrate that PHS1-mediated tubulin phosphorylation in angiosperms starts ca. 5 min after hyperosmotic stress and results in destabilization of interphase microtubule arrays.

In Chlamydomonas, we showed that PHS1 phosphorylates Thr349 of $\alpha$-tubulin $10 \mathrm{~min}$ after application of $>0.2 \mathrm{M}$ (i.e., > 200 mosM) sorbitol in both G1 phase and mitotic cells, and causes fragmentation of cytoplasmic microtubules after $10 \mathrm{~min}$. Since the cytosolic osmolarity of Chlamydomonas cells is approximately 170 mosM [24], this response is caused by mild hyperosmotic stress. Although mitotic microtubule arrays were not examined in our study, due to technical difficulties to precisely define dense mitotic microtubule structures, mitotic arrays are likely destabilized by rapid tubulin phosphorylation. It appears that activation of PHS1 tubulin kinase activity occurs both in G1 phase and mitotic cells immediately upon hyperosmotic stress.

We showed that stress-induced tubulin phosphorylation is transient, even when osmotic stress persists; in the continuous presence of $>0.2 \mathrm{M}$ sorbitol, phosphorylated Chlamydomonas tubulins are mostly de-phosphorylated after $1 \mathrm{~h}$ in $\mathrm{G} 1$ phase cells and after $3 \mathrm{~h}$ in mitotic cells. We do not know what causes the observed differences in the steady-state levels of phosphorylated tubulins under continuous stress during the cell cycle. De-activation (or de-sensitization) of the PHS1 tubulin kinase, as commonly observed for stress-activated MPKs [25], increased activity of putative tubulin de-phosphatases during continuous stress, or both, may be responsible for this phenomena.

Previous studies showed that Thr349 of $\alpha$-tubulin is phosphorylated by stresses caused either by salt $(\mathrm{NaCl})$ or osmotic agents (mannitol or sorbitol) [3, 22, 23]. Since salt stress to plants involves both ionic imbalance and hyperosmotic effects [26], we compared the effects of $\mathrm{NaCl}$ and sorbitol at the equivalent morality, and found that tubulin phosphorylation is mainly triggered by 
hyperosmotic stress, whereas $\mathrm{NaCl}$ inhibits cell growth strongly by ionic imbalance. Sensing mechanisms of salinity and osmotic stress are distinct in plants, but the molecular identities of responsible sensors and receptors are still largely elusive [27].

\section{Hyperosmotic stress responses in Chlamydomonas}

Responses of Chlamydomonas cells to salinity stress (a combination of hyperosmotic and ionic stresses) have been studied (reviewed in [28]), and include alterations in morphology [29], photobiology [30], transcriptomes [31], proteomes [32], and plus-end dynamics of cytoplasmic microtubules [33]. Relevant studies on hyperosmotic stress are very limited; to our knowledge, only one study reports metabolomics changes of Chlamydomonas cells to hyperosmotic stress after $5 \mathrm{~h}$ [34].

We found that hyperosmotic stress causes PHS1-mediated transient tubulin phosphorylation and microtubule destabilization, as well as inhibition of daughter cell release after cell division. Newly divided daughter cells in Chlamydomonas and related green algae are encapsulated in the mucilage rich in acidic polysaccharides [35] and hydroxyproline-containing glycoproteins [36]. Various environmental stresses [37], including salinity (e.g., [38]), inhibit hatching, resulting in formation of daughter cell aggregates, called "palmelloids". Although physiological roles of palmelloid formation are not well known, it has been proposed that formation of large cell aggregates enables the algal cells to better escape herbivory from grazing zooplanktons [39].

\section{Possible roles of PHS1-mediated microtubule destabilization}

The spindle assembly checkpoint (SAC) functions as a surveillance mechanisms to ensure equal segregation of chromosomes during cell division, by arresting metaphase until all chromosomes are correctly attached to spindle microtubules [40]. Land plants and green algae possess both shared and unique cell cycle control components, compared with yeast and animals [41], and display compromised SAC responses. When spindle microtubules were not formed by treating Arabidopsis roots with a high dosage $(1 \mu \mathrm{M})$ of oryzalin, a microtubule depolymerizing drug, metaphase cells were transiently arrested by SAC but re-initiated the cell cycle after $\sim 2 \mathrm{~h}$ without subsequent cell division to attain polyploidy [42]. Such short-lived SAC functions during severe stress may have promoted frequent genome duplication during plant genome evolution [42]. DNA re-replication was also observed in Chlamydomonas cells when treated with a high dosage of the microtubule-depolymerizing drug amiprophos-methyl for a prolonged duration or disrupted in genes involved in tubulin folding chaperones or a microtubule nucleation [43]. Thus, severe disruption of mitotic microtubules in land plants and green algae does not abolish progression of the cell cycle due to transient SAC functions.

Our studies reveal that PHS1 might play a role in delaying cell cycle progression in Chlamydomonas under mild osmotic stress conditions. Moderate destabilization of mitotic microtubules by lower dosages of oryzalin $(<0.2 \mu \mathrm{M})$ delayed the progression of mitosis in Arabidopsis roots in a SAC-dependent manner [42]. Hyperosmotic stress by $0.3 \mathrm{M}$ sorbitol might cause sufficient microtubule destabilization that would result in the cell cycle delay in Chlamydomonas cells. It will be interesting to study whether PHS1-mediated microtubule destabilization directly or indirectly causes the cell cycle delay, and whether the stress-responsive cell cycle regulation requires canonical SAC functions. Also, long-term effects of moderate hyperosmotic stress on chromosome segregation errors and genome instability worth investigation.

During G1 phase, hyperosmotic stress-triggered transient microtubule destabilization does not affect cell growth (the rate of cell volume increase). What roles might the PHS1-mediated microtubule destabilization have for cellular responses to hyperosmotic stress in the G1 phase algal cells? Future studies need to address whether cell behavior and motility, such as chemotaxis and phototaxis, are affected by the stress.

\section{Conclusion}

In freshwater green algae Chlamydomonas reinhardtii, PHS1 tubulin kinase was activated by mild hyperosmotic stress and rapidly and transiently phosphorylated $\alpha$-tubulin at a critical Thr residue required for efficient polymerization. Tubulin phosphorylation resulted in transient disassembly of interphase microtubules. Hyperosmotic stress-induced transient tubulin phosphorylation delayed progression of mitosis, and is thought to be partly responsible for stress-responsive cell cycle delay. Presence of PHS1 homologues in many freshwater living green algae indicate their possible roles in salinity response.

\section{Methods}

\section{Strains, media and culturing conditions}

C. reinhardtii wild-type strain CC-4533 and PHS1 insertion mutant LMJ.RY0402.181368 (phs1-1) were obtained from Chlamydomonas Library Project (https://www. chlamylibrary.org/ [44];). Chlamydomonas cells were maintained and cultured in the Tris-acetate-phosphate (TAP) medium $\left(0.4 \mathrm{gL}^{-1} \mathrm{NH}_{4} \mathrm{Cl}, 0.1 \mathrm{~g} / \mathrm{L} \mathrm{MgSO}_{4} \cdot 7 \mathrm{H}_{2} \mathrm{O}\right.$, $0.05 \mathrm{gL}^{-1} \mathrm{CaCl}_{2} \cdot 2 \mathrm{H}_{2} \mathrm{O}, 0.108 \mathrm{gL}^{-1} \mathrm{~K}_{2} \mathrm{HPO}_{4} \cdot 0.056 \mathrm{gL}^{-1}$ $\mathrm{KH}_{2} \mathrm{PO}_{4}, \quad 2.42 \mathrm{gL}^{-1}$ Tris, $1 \mathrm{mLL}^{-1}$ glacial acetic acid, $5 \mathrm{mg} \mathrm{L}^{-1} \mathrm{Na}_{2} \cdot$ EDTA, $2.2 \mathrm{mgL}^{-1} \quad \mathrm{ZnSO}_{4} \cdot 7 \mathrm{H}_{2} \mathrm{O}$. 
$1.14 \mathrm{mg} \mathrm{L}^{-1} \mathrm{H}_{3} \mathrm{BO}_{3}, 5.1 \mathrm{mg} \mathrm{L}^{-1} \mathrm{MnCl}_{2} \cdot 4 \mathrm{H}_{2} \mathrm{O}, 0.5 \mathrm{mg} \mathrm{L}^{-1}$ $\mathrm{FeSO}_{4} \cdot 7 \mathrm{H}_{2} \mathrm{O}, \quad 0.16 \mathrm{mg} \mathrm{L}^{-1} \quad \mathrm{CoCl}_{2} \cdot 6 \mathrm{H}_{2} \mathrm{O}, \quad 0.16 \mathrm{mg} \mathrm{L}^{-1}$ $\mathrm{CuSO}_{4} \cdot 5 \mathrm{H}_{2} \mathrm{O}, \quad 0.11 \mathrm{mg} \mathrm{L}^{-1} \quad\left(\mathrm{NH}_{4}\right)_{6} \mathrm{Mo}_{7} \mathrm{O}_{24} \cdot 4 \mathrm{H}_{2} \mathrm{O}$ and $\left.1.6 \mathrm{mgL}^{-1} \mathrm{KOH}\right)$. Stock solutions of $3 \mathrm{M} \mathrm{NaCl}$ and $3 \mathrm{M}$ sorbitol were diluted prior to each experiment to give indicated final concentrations. A commercial seawater mixture (GEX Co., Osaka, Japan) was dissolved in sterilized water to prepare artificial seawater.

To synchronize cell growth, cells were grown in $25 \mathrm{~mL}$ of the TAP liquid medium with horizontal shaking at $100 \mathrm{rpm}$ in an incubator shaker under white light $\left(224 \mu \mathrm{mol}\right.$ photons $\left.\mathrm{m}^{-2} \mathrm{~s}^{-1}\right)$ with a light:dark (12 h:12 h) photoperiod. Prior to the start of the synchronized culture, cells were diluted to $\mathrm{OD}_{750}=0.05$ at the beginning of the light regime for several days. Approximately $2 \times 10^{5}$ cells were inoculated into $25 \mathrm{~mL}$ medium. The temperature in the incubator shaker was set at $26^{\circ} \mathrm{C}$ during illumination and at $22^{\circ} \mathrm{C}$ during the dark regime.

\section{Search for PHS1 homologues}

The Arabidopsis thaliana PHS1 protein sequence (NP_851066.2) was used as a query against genome sequences deposited in Phytozome, Phycocosm, ConGenIE and GenBank at National Center for Biotechnology Information (NCBI). PHS1 homologues were identified with two criteria: (a) a tubulin kinase domain (which contains three catalytically critical amino acid residues, corresponding to K187, D309, and N324 in A. thaliana PHS1) juxtaposed with a MAP kinase phosphatase domain in a single ORF, and (b) confidence value/Expect (E)-value less than $\mathrm{e}^{-10}$ of the kinase domain.

\section{Cell number and cell size analysis}

The Z2 Cell and Particle Counter (Beckman Coulter) was used to measure the number of cells and the cell volume. Cells in the sampled $100 \mu \mathrm{L}$ culture were first fixed with $1 \%$ glutaraldehyde and then immediately mixed with $10 \mathrm{~mL}$ of Isoton II diluent (Beckman Coulter). The cell size range was set between 60 to $3400 \mu \mathrm{m}^{3}$. Data was exported using Coulter Z2 AccuComp. (Beckman Coulter).

Statistical significance in growth rate was calculated by one-way ANOVA (Analysis of Variance) with Tukey HSD (Tukey Honest Significant Differences) post-hoc test, using R statistical software ver3.6.3.

\section{Plasmid construction and transformation}

A hygromycin selectable marker [45] was cloned between the EcoRV and KpnI sites of pBluescript II KS (+) plasmid. A genomic fragment of PHS1 (11,063bp) was released from the fosmid clone (GCRFno27_g18 from the C. reinhardtii $\mathrm{C} 9$ strain) by digestion with HindIII and cloned into the HindIII site of the above pBluescript II plasmid to generate pgCrPHS1.

Transformation was performed according to [46] with some modifications. Fresh overnight culture of Chlamydomonas cells were centrifuged at $600 \mathrm{x} g$ for $5 \mathrm{~min}$ and washed twice with $10 \mathrm{~mL}$ of MAX Efficiency Transformation Reagent for Algae (Invitrogen). The $1 \times 10^{8}$ cells and approximately $1 \mu \mathrm{g}$ of the XbaI-restricted pgCrPHS1 plasmid were mixed and then transferred to an electroporation cuvette. After incubation for $5 \mathrm{~min}$ at $4{ }^{\circ} \mathrm{C}$, a single electric pulse with voltage of $0.4 \mathrm{kV}$ for about $4 \mathrm{~s}$ was applied using MicroPulser ${ }^{\mathrm{TM}}$ (Bio-Rad). Electroporated cells were transferred to $10 \mathrm{~mL}$ of TAP medium containing $40 \mathrm{mM}$ sucrose and were grown under dim light overnight. The cells were then spread onto TAP agar plate containing $30 \mu \mathrm{g} \mathrm{mL}^{-1}$ hygromycin, and grown for 5 days. Putative transformants were picked and checked by genomic PCR analysis.

\section{DNA extraction and polymerase chain reaction (PCR)}

Chlamydomonas cells grown on a TAP agar plate were mixed well in $50 \mu \mathrm{L}$ of $5 \%$ Chelex (Invitrogen) and were vortexed for $15 \mathrm{~s}$ before subjected to $100^{\circ} \mathrm{C}$ for $10 \mathrm{~min}$. The tube was then placed on ice for $1 \mathrm{~min}$ and centrifuged at $12,000 \mathrm{rpm}$ for $2 \mathrm{~min}$. The supernatant was transferred to a new tube and was used for PCR analysis. Each sample contained a final concentration of $1 \times$ PCR buffer for KOD FX Neo, $0.4 \mathrm{mM}$ dNTP, $0.2 \mu \mathrm{M}$ PCR forward and reverse primers, $0.5 \mu \mathrm{L}$ KOD FX Neo, $0.5 \mu \mathrm{L}$ of DNA template, and sterile water to fill up to $25 \mu \mathrm{L}$. PCR conditions: $95^{\circ} \mathrm{C}$ for $5 \mathrm{~min}$; followed by 30 cycles of $95^{\circ} \mathrm{C}$ for $5 \mathrm{~s}, 58^{\circ} \mathrm{C}$ for $45 \mathrm{~s}$ and $72{ }^{\circ} \mathrm{C}$ for $1 \mathrm{~min}$, and finally $72^{\circ} \mathrm{C}$ for $2 \mathrm{~min}$. The primers sequences: PHS1_P1, $5^{\prime}-\mathrm{CACACA}$ TAGGTGACAATGGGACAC-3', PHS1_P2, 5'-GCA GCAGTAGCAACATAAGCAGTA-3' and LB, 5'-TGG GCGCCGTAGTTAAGACAAA-3'.

\section{Quantitative real-time PCR}

Chlamydomonas cells were harvested by centrifugation at $600 \mathrm{x} g$ for $5 \mathrm{~min}$ and disrupted by mortar and pestle with liquid nitrogen. Total RNA was extracted by using RNeasy Mini kit (Invitrogen) according to the manufacturer's instructions. Cell homogenates were mixed with $450 \mu \mathrm{L}$ of the RLT buffer and transferred to a QIA shredder spin column. After centrifugation, the flow-through fraction was collected and $225 \mu \mathrm{L}$ of $100 \%$ ethanol was added. The mixture was transferred to an RNeasy spin column. After centrifugation at $8000 \mathrm{x} g$ for $15 \mathrm{~s}, 700 \mu \mathrm{L}$ of RW1 buffer was added to the column and subjected to centrifugation at $8000 \times \mathrm{g}$ for $15 \mathrm{~s}$. The flow-through fraction was discarded. A total of $500 \mu \mathrm{L}$ RPE buffer was added to the column and again centrifuged at $8000 \mathrm{x} g$ for $15 \mathrm{~s}$. This step was repeated using $500 \mu \mathrm{L}$ RPE buffer but 
with centrifugation for $2 \mathrm{~min}$. The column was carefully transfer to a new $1.5-\mathrm{mL}$ centrifuge tube. Finally, $30 \mu \mathrm{L}$ of RNase free water was added into the column and centrifuged at $10,000 \times \mathrm{g}$ for $1 \mathrm{~min}$ and kept at $-80^{\circ} \mathrm{C}$ until use.

ReverTraAce ${ }^{\circledR} \mathrm{qPCR}$ MasterMix with gDNA remover (Toyobo) was used to reverse transcript RNA. A total of $0.5 \mu \mathrm{g}$ of RNA was used per reaction. All samples were heated to $65^{\circ} \mathrm{C}$ for $5 \mathrm{~min}$ and transferred to ice immediately. Then, $4 \mathrm{x}$ DN master mix was added. After the samples were incubated for $37^{\circ} \mathrm{C}$ for $5 \mathrm{~min}, 5 \times \mathrm{RT}$ master mix was added into the reaction mixture and then subjected for incubation: $37^{\circ} \mathrm{C}$ for $15 \mathrm{~min}, 50^{\circ} \mathrm{C} 5 \mathrm{~min}, 98^{\circ} \mathrm{C}$ for $5 \mathrm{~min}$. The cDNA preparations were kept at $-20^{\circ} \mathrm{C}$ until use.

RT-qPCR was performed using Light Cycler 96 (Roche) with TB Green ${ }^{\mathrm{TM}}$ Premix Ex Ta ${ }^{\mathrm{TM}}$ II (Takara). Each sample consists of a final concentration of $1 \times$ TB Green Premix Ex Taq II, $0.4 \mu \mathrm{M}$ of PCR forward and reverse primers, and $1 \mu \mathrm{L}$ of cDNA template top up to $10 \mu \mathrm{L}$. The thermal program was $95^{\circ} \mathrm{C}$ for $30 \mathrm{~s}$, followed by 40 cycles of $95^{\circ} \mathrm{C}$ for $5 \mathrm{~s}$ and $60^{\circ} \mathrm{C}$ for $30 \mathrm{~s}, 1 \mathrm{cycle}$ of $95^{\circ} \mathrm{C}$ for $5 \mathrm{~s}$, $60^{\circ} \mathrm{C}$ for $1 \mathrm{~min}$, and finally $50^{\circ} \mathrm{C}$ for $30 \mathrm{~s}$. A sodium/phosphate symporter gene (PTB-1) was used as a reference gene. Primers sequences for qPCR: PTB1-F, $5^{\prime}$-GCCTAC TCGCCCAGCATC-3', and PTB1-R, 5'-TGTTGGTGC GGTTGAGCA-3'; CDKB-F, 5'-ACCTGCACCGCATCT TCC-3' ${ }^{\prime}$, and CDKB-R 5'-GGGTGGTTGATCGCCTCC -3'; CYCB-F, 5'-TGCCCAGCGACTACATGAC-3', and CYCB-R, 5'-CGTCTCGGGCATCAGCTT-3'.

\section{Protein extraction}

Chlamydomonas cells were harvested by centrifugation at $600 \mathrm{xg}$ for $5 \mathrm{~min}$, quick frozen in liquid nitrogen, and crushed with mortar and pestle. Protein extraction buffer [20 mM sodium phosphate buffer (pH7.4) containing $100 \mu \mathrm{M} \mathrm{Na} \mathrm{NO}_{4}, 50 \mathrm{mM} \quad \beta$-glycerophosphate, $0.5 \mathrm{mM}$ phenylmethanesulfonylfluoride and one tablet of Complete Protease Inhibitor Cocktail (Roche)] was used to resuspend the cells. After centrifugation at $15,000 \times \mathrm{g}$ for $20 \mathrm{~min}$, the cell extracts were transferred to a new tube, added with 3 times volume of acetone, and incubated overnight at $-20^{\circ} \mathrm{C}$. The protein extract was centrifuged at $15,000 \times \mathrm{g}$ for $10 \mathrm{~min}$ and re-suspended in $1 \mathrm{x}$ sample buffer $(62.5 \mathrm{mM}$ Tris- $\mathrm{HCl}$, pH 6.8, 2.5\% SDS, $0.002 \%$ bromophenol, $10 \%$ glycerol). The protein concentration was measured using RC DC Protein Assay (Bio-rad) by using bovine serum albumin as a control. The absorbance readings were taken using Ultrospec $3000 \mathrm{UV} /$ Visible spectrophotometer (Pharmacia Biotech) at $750 \mathrm{~nm}$.

\section{Immunoblotting}

Proteins $(20 \mu \mathrm{g})$ were resolved on $10 \%$ SDS-PAGE (Resolving gel: $375 \mathrm{mM}$ Tris- $\mathrm{HCl}, 10 \%$ acrylamide, $0.1 \%$
SDS, 0.1\% APS and 0.04\% TEMED; stacking gel: $147 \mathrm{mM}$ Tris- $\mathrm{HCl}, 5 \%$ acrylamide, $0.1 \%$ SDS, $0.1 \%$ APS and $0.1 \%$ TEMED) with a $1 \times$ SDS running buffer $(25 \mathrm{mM}$ Tris, $192 \mathrm{mM}$ glycine and 0.1\% SDS). For phos-tag 10\% SDSPAGE, $50 \mathrm{mM} \mathrm{MnCl}$ and $25 \mu \mathrm{M}$ Phos-tag (Wako) were added in addition of $10 \%$ SDS PAGE resolving gel mixture. The SDS PAGE electrophoresis were performed using voltage of $300 \mathrm{~V}, 40 \mathrm{~mA}$ for $100 \mathrm{~min}$. After electrophoresis, the gel was washed in transfer buffer $(25 \mathrm{mM}$ Tris, $192 \mathrm{mM}$ glycine and $10 \%$ methanol) for $5 \mathrm{~min}$. Phos-tag gel was washed in the transfer buffer containing $10 \mathrm{mM}$ EDTA. The proteins were then blotted onto a polyvinylidene fluoride (PVDF) membrane (ImmobilonP, Merck Milipore) and electrophoresis was performed using transfer buffer for $60 \mathrm{~min}$ at $100 \mathrm{~V}, 400 \mathrm{~mA}$. After electrophoresis, the membrane was washed with TBS-T buffer $(20 \mathrm{mM}$ Tris, $150 \mathrm{mM} \mathrm{NaCl}$ and $0.1 \%$ Tween 20$)$ before blocked with blocking buffer (5\% skim milk in TBS-T) for $1 \mathrm{~h}$. Then, the blotted membrane was incubated overnight with a primary antibody in the blocking buffer. Primary antibodies used in this study were anti$\alpha$-tubulin mouse antibody (B-5-1-2) (1:100,000 dilution) (Sigma) and anti-pT349 rabbit antibody (1:5000 dilution) [6]. After washing with TBS-T three times, the membrane was incubated with anti-mouse IgG, HRP-linked antibody (GE-Healthcare; 1:10,000 dilution) or anti-rabbit IgG, HRP-linked antibody (GE-Healthcare; 1:10,000 dilution) as secondary antibodies in the blocking buffer for $1 \mathrm{~h}$. Immobilon western chemiluminescent HRP substrate (Milipore) was used for immunoblot detection. Chemiluminescence was detected using ImageQuant LAS4000 (GE Healthcare Life Sciences) and quantified by using Image J.

\section{Microscopy analyses}

For immunofluorescence analysis, approximately $100 \mu \mathrm{L}$ of Chlamydomonas cells were placed on a clean polylysine-coated microscopy slide, which had been prepared by treating the slide with $0.1 \mathrm{mg} / \mathrm{mL}$ of polylysine solution (Sigma-Aldrich) for $15 \mathrm{~min}$. After immobilizing the cells on the polylysine slide for $5 \mathrm{~min}$, $100 \mu \mathrm{L}$ of PBS containing $4 \%(\mathrm{w} / \mathrm{v})$ formaldehyde were applied to the cells for another $20 \mathrm{~min}$. After washing with PBS three times, the slide was immersed in chilled methanol at $-20^{\circ} \mathrm{C}$ for $20 \mathrm{~min}$. The slide was washed with PBS three times again. Then, the slide was treated with $100 \mu \mathrm{L}$ of blocking solution $[5 \%(\mathrm{w} / \mathrm{v})$ BSA in PBS-T buffer (PBS solution added with $0.1 \%$ of Tween 20)] for $1 \mathrm{~h}$, and then with primary antibodies. For double-labeling immunofluorescence experiments, anti- $\alpha$-tubulin rat antibody (YOL 1/34) (Milipore) and anti-acetylated $\alpha$-tubulin mouse antibody (B-6-1-1) (Sigma) were used. All primary antibodies were applied 
at a dilution ratio of 1:2000. The slide was incubated at $4{ }^{\circ} \mathrm{C}$ overnight, washed with PBS-T for three times, and then incubated with goat anti-rat Alexa Fluor ${ }^{\circledR}$ 488 (Invitrogen) and goat anti-mouse Alexa Fluor ${ }^{\circledR}$ 568 (Invitrogen) with a dilution ratio of 1:200 for $1 \mathrm{~h}$. After washing with PBS-T three times, the slide was treated with a mounting solution (100 mM Tris, $50 \%$ glycerol and $1 \mathrm{mg} / \mathrm{mL}$ para-phenylenediamine) and covered with $22 \times 22 \mathrm{~mm}$ coverslip. Microscopy slides were examined with a Nikon Eclipse Ti-U microscope equipped with a Yokogawa CSU-XI spinning disc confocal unit and Nikon 100x/1.30 oil immersion objective lens. Images were captured and recorded at $0.5 \mu \mathrm{m}$ intervals at the wavelength of $488 \mathrm{~nm}$ and $568 \mathrm{~nm}$ by using Andor iXon3 DU897 EM-CCD camera. All images were documented by stacking using $\mathrm{Z}$ series. Image $J$ was used to merge images of two chromophores, and the brightness was adjusted. Binary image of Chlamydomonas cells created by image J was used to evaluate the occupancy of microtubules in cell body over the cell size. Statistical significance between the means of group was calculated by one-way ANOVA with Tukey HSD post-hoc test, where $p$-value $<0.01$ indicates significantly different.

For bright field microscopy, cells were treated with $1 \%$ glutaraldehyde and placed onto a microscope slide. Microscope slides were examined by using Nikon Eclipse E600 fluorescence microscope (Nikon) with Nikon 40x/0.75 objective lens. All mages were captured using Olympus DP70 camera and documented using DP controller software (Olympus).

\section{Abbreviations}

ABA: Abscisic acid; MPK: Mitogen-activated Protein Kinase; PCR: Polymerase chain reaction; PHS1: Propyzamide Hypersensitive 1; SAC: Spindle assembly checkpoint; SDS-PAGE: Sodium dodecyl sulfate-polyacrylamide gel electrophoresis.

\section{Supplementary Information}

The online version contains supplementary material available at https://doi. org/10.1186/s12870-022-03439-6.

Additional file 1: Figure S1. Cell size distribution in a 12/12h of light/dark diurnal cycle. Figure S2. Growth (cell volume increase) of Chlamydomonas cells in the control medium, or in the culture medium containing $0.3 \mathrm{M}$ sorbitol or $0.15 \mathrm{M} \mathrm{NaCl}$. Figure S3. Immunoblots of tubulins in various Chlamydomonas strains. Figure S4. T-DNA insertion mutant of PHS1. Figure S5. Original fluorescence images and the corresponding binary images of microtubules generated by Image J. Figure S6. Amino acid sequence alignment of putative kinase domains from green algae PHS1 homologues.

Additional file 2:. Uncropped versions of immunoblots and an agarose gel.

\section{Acknowledgments}

The authors thank Prof. Bo Liu (University of California, Davis) for useful advice on immunofluorescence microscopy analysis.

\section{Authors' contributions}

TH and SK designed the research, NLM and HT performed the experiments, and all authors analyzed and interpreted the data. After TH and NLM prepared the draft manuscript, all authors read and contributed to the final manuscript.

\section{Funding}

This work was supported by Grant-in-Aid for Scientific Research (B) to T.H. (17H03698) from Japan Society for the Promotion of Science (JSPS), Japan.

\section{Availability of data and materials}

Materials generated in this work will be provided after reasonable requests to $\mathrm{TH}$.

\section{Declarations}

Ethics approval and consent to participate

Not applicable.

\section{Consent for publication}

Not applicable.

\section{Competing interests}

The authors declare that they have no competing interests.

\section{Author details}

${ }^{1}$ Graduate School of Science and Technology, Nara Institute of Science and Technology, Ikoma, Nara 630-0192, Japan. ${ }^{2}$ Graduate School of Biostudies, Kyoto University, Kyoto, Kyoto 606-8502, Japan.

Received: 10 August 2021 Accepted: 10 January 2022

Published online: 22 January 2022

\section{References}

1. Cheng S, Xian W, Fu Y, Marin B, Keller J, Wu T, et al. Genomes of subaerial Zygnematophyceae provide insights into land plant evolution. Cell. 2019:179:1057-67.

2. Naoi K, Hashimoto T. A semidominant mutation in an Arabidopsis mitogen-activated protein kinase phosphatase-like gene compromises cortical microtubule organization. Plant Cell. 2004;16(7):1841-53.

3. Fujita S, Pytela J, Hotta T, Kato T, Hamada T, et al. An atypical tubulin kinase mediates stress-induced microtubule depolymerization in Arabidopsis. Curr Biol. 2013;23(20):1969-78.

4. Hotta T, Fujita S, Uchimura S, Noguchi M, Demura T, et al. Affinity purification and characterization of functional tubulin from cell suspension cultures of Arabidopsis and tobacco. Plant Physiol. 2016;170(3):1189-205.

5. Bisova K, Krylov DM, Umen JG. Genome-wide annotation and expression profiling of cell cycle regulatory genes in Chlamydomonas reinhardtii. Plant Physiol. 2005;137(2):475-91.

6. Tulin F, Cross FR. Cyclin-dependent kinase regulation of diurnal transcription in Chlamydomonas. Plant Cell. 2015;27(10):2727-42.

7. Werth EG, MCConnell EW, Gilbert TSK, Lianez IC, Perez CA, et al. Probing the global kinome and phosphoproteome in Chlamydomonas reinhardtii via sequential enrichment and quantitative proteomics. Plant J. 2017;89:416-26.

8. Verslues PE, Agarwal M, Katiyar-Agarwal S, Zhu J, Zhu JK. Methods and concepts in quantifying resistance to drought, salt and freezing, abiotic stresses that affect plant water status. Plant J. 2006;45(4):523-39.

9. Monk BC, Adair WS, Cohen RA, Goodenough UW. Topography of Chlamydomonas: fine structure and polypeptide components of the gametic flagellar membrane surface and the cell wall. Planta. 1983;158:517-33.

10. Kinoshita E, Kinoshita-Kikuta E, Takiyama K, Koike T. Phosphate-binding tag, a new tool to visualize phosphorylated proteins. Mol Cell Proteomics. 2006;5:749-57. 
11. Orbach R, Howard J. The dynamics and structural properties of axonemal tubulins support the high length stability of cilia. Nat Commun. 2019;10:1838

12. Van de Weghe JC, Harris JA, Kubo T, Witman GB, Lechtreck KF. Diffusion rather than intraflagellar transport likely provides most of the tubulin required for axonemal assembly in Chlamydomonas. J Cell Sci. 2020;133:jes249805.

13. Xu Z, Schaedel L, Portran D, Aguilar A, Gaillard J, et al. Microtubules acquire resistance from mechanical breakage through intraluminal acetylation. Science. 2017;356:328-32.

14. LeDizet M, Piperno G. Cytoplasmic microtubules containing acetylated alpha-tubulin in Chlamydomonas reinhardtii: spatial arrangement and properties. J Cell Biol. 1986;103(1):13-22.

15. Piperno G, Fuller MT. Monoclonal antibodies specific for an acetylated form of alpha-tubulin recognize the antigen in cilia and flagella from a variety of organisms. J Cell Biol. 1985;101(6):2085-94.

16. Umen JG. Sizing up the cell cycle: systems and quantitative approaches in Chlamydomonas. Curr Opin Plant Biol. 2018;46:96-103.

17. Steinbacher S, Hof P, Eichinger L, Schleicher M, Gettemans J, et al. The crystal structure of the Physarum polycephalum actin-fragmin kinase: an atypical protein kinase with a specialized substrate-binding domain. EMBO J. 1999;18:2923-9.

18. Gettemans J, De Ville Y, Vandekerckhove J, Waelkens E. Physarum actin is phosphorylated as the actin-fragmin complex at residues Thr203 and Thr202 by a specific 80 kDa kinase. EMBO J. 1992;11:3185-91.

19. Eichinger L, Bomblies L, Vandekerckhove J, Schleicher M, Gettemans J. A novel type of protein kinase phosphorylates actin in the actin-fragmin complex. EMBO J. 1996;15:5547-56.

20. Theodosiou A, Ashworth A. MAP kinase phosphatases. Genome Biol. 2002;3:3009.

21. Umezawa T, Sugiyama N, Takahashi F, Anderson JC, Ishihama Y, et al. Genetics and phosphoproteomics reveal a protein phosphorylation network in the abscisic acid signaling pathway in Arabidopsis thaliana. Sci Signal. 2013;6(270):rs8-rs8.

22. Stecker KE, Minkoff BB, Sussman MR. Phosphoproteomic analyses reveal early signaling events in the osmotic stress response. Plant Physiol. 2014;165:1171-87.

23. Ban Y, Kobayashi Y, Hara T, Hamada T, Hashimoto T, et al. a-Tubulin is rapidly phosphorylated in response to hyperosmotic stress in rice and Arabidopsis. Plant Cell Physiol. 2013;54(6):848-58.

24. Komsic-Buchmann $K$, Wüstehoff $L$, Becker B. The contractile vacuole as a key regulator of cellular water flow in Chlamydomonas reinhardtii. Eukaryot Cell. 2014;13:1421-30.

25. Muzzey D, Gomez-Uribe CA, Mettetal JT, van Oudenaarden A. A systemslevel analysis of perfect adaptation in yeast osmoregulation. Cell. 2009;138:160-71.

26. Verslues PE, Agarwal M, Katiyar-Agarwal S, Zhu J, Zhu JK. Methods and concepts in quantifying resistance to drought, salt and freezing, abiotic stresses that affect plant water status. Plant J. 2006:45(4):523-39.

27. Lamers J, van der Meer T, Testerink C. How plants sense and respond to stressful environments. Plant Physiol. 2020;182:1624-35.

28. Shetty P, Gitau MM, Maròti G. Salinity stress responses and adaptation mechanisms in eukaryotic green microalgae. Cells. 2019:8:1657.

29. Khona DK, Shirolikar SM, Gawde KK, Hom E, Deodhar MA, et al. Characterization of salt stress-induced palmelloids in the green algae, Chlamydomonas reinhardtii. Algal Res. 2016;16:434-48.

30. Neelam S, Subramanyam R. Alteration of photochemistry and protein degradation of photosystem II from Chlamydomonas reinhardtii under high salt grown cells. J Photochem Photobiol B Biol. 2013;124:63-70.

31. Wang N, Qian Z, Luo M, Fan S, Zhang X, et al. Identification of salt stress responding genes using transcriptome analysis in green algae Chlamydomonas reinhardtii. Int J Mol Sci. 2018;19:3359.

32. Sithtisarn S, Yokthongwattana K, Mahong B, Roytrakul S, Paemanee A, et al. Comparative proteomic analysis of Chlamydomonas reinhardtii control and a salinity-tolerant strain revealed by a differential protein expression pattern. Planta. 2017;246:843-56

33. Liu Y, Visetsouk M, Mynlieff M, Qin H, Lechtreck KF, et al. H+-and Na+elicited rapid changes of the microtubule cytoskeleton in the biflagellated green alga Chlamydomonas. eLife. 2017;6:e26002.
34. Tietel Z, Wikoff WR, Kind T, Ma Y, Fiehn O. Hyperosmotic stress in Chlamydomonas induces metabolomics changes in biosynthesis of complex lipids. Eur J Phycol. 2020;55:11-29.

35. Crayton MA. A comparative cytochemical study of Vovocacean matrix polysaccharides. J Phycol. 1982;18:336-44.

36. Miller DH, Mellman IS, Lamport DTA, Miller M. The chemical composition of the cell wall of Chlamydomonas gymnogama and the concept of a plant cell wall protein. J Cell Biol. 1974;63:420-9.

37. De Carpentier F, Lemaire SD, Danon A. When unity is strength: the strategies used by Chlamydomonas to survive environmental stresses. Cells. 2019;8:1307.

38. Khona DK, Shirolikar SM, Gawde KK, Hom E, Deodhar MA, et al. Characterization of salt stress-induced palmelloids in the green algae, Chlamydomonas reinhardti. Algal Res. 2019;16:434-48.

39. Lurling M, Beekman W. Palmelloids formation in Chlamydomonas reinhardtii: defense against rotifer predators? Ann. Limnol - Int J Lim. 2006;42:65-72.

40. London N, Biggins S. Signalling dynamics in the spindle checkpoint response. Nat Rev Mol Cell Biol. 2014;15:736-47.

41. Komaki S, Schnittger A. The spindle checkpoint in plants - a green variation over a conserved theme. Curr Opin Plant Biol. 2016;34:84-91.

42. Komaki S, Schnittger A. The spindle assembly checkpoint in Arabidopsis is rapidly shut off during severe stress. Dev Cell. 2017;43(2):172-85.

43. Tulin F, Cross FR. A microbial avenue to cell cycle control in the plant superkingdom. Plant Cell. 2014;26:4019-38.

44. Li X, Zhang R, Patena W, Gang SS, Blum SR, et al. An indexed, mapped mutant library enables reverse genetics studies of biological processes in Chlamydomonas reinhardtii. Plant Cell. 2016;28:367-87.

45. Berthold P, Schmitt R, Mages W. An engineered Streptomyces hygroscopicus aph 7 " gene mediates dominant resistance against hygromycin B in Chlamydomonas reinhardtii. Protist. 2002;153(4):401.

46. Yamano T, Iguchi H, Fukuzawa H. Rapid transformation of Chlamydomonas reinhardtii without cell-wall removal. J Biosci Bioeng. 2013;115(6):691-4

\section{Publisher's Note}

Springer Nature remains neutral with regard to jurisdictional claims in published maps and institutional affiliations.

Ready to submit your research? Choose BMC and benefit from

- fast, convenient online submission

- thorough peer review by experienced researchers in your field

- rapid publication on acceptance

- support for research data, including large and complex data types

- gold Open Access which fosters wider collaboration and increased citations

- maximum visibility for your research: over 100M website views per year

At BMC, research is always in progress.

Learn more biomedcentral.com/submissions 